10-10-2018

\title{
Embedding Sustainability in Lean Six Sigma Efforts
}

Nadiye O. Erdil

Can B. Aktas

Omid M. Arani

Follow this and additional works at: https://digitalcommons.newhaven.edu/mechanicalengineeringfacpubs

Part of the Industrial Engineering Commons, and the Mechanical Engineering Commons

\section{Comments}

This is the authors' accepted version of the article published in Journal of Cleaner Production.

Full-text available for the University of New Haven Community. 


\title{
Embedding Sustainability in Lean Six Sigma Efforts
}

\begin{abstract}
The emphasis on the concept of sustainability in businesses and operations is growing either due to increasing public interest, regulatory pressures, or corporate social responsibility. However, where and how to integrate sustainability needs further development for broadening its applications. Using Lean and Six Sigma (LSS) principles in sustainability studies is becoming popular in research and practice. The common approach in these studies is to identify a sustainability project followed by current state sustainability performance assessment, and then work towards improving sustainability performance using LSS tools. The goal of this study was to develop a model framework to fully embed sustainability into any LSS project building on current practices. The wide coverage of LSS, its effectiveness record, and its overlap with sustainability goals establish the foundation for expanding LSS methodology to include sustainability concepts. The proposed framework is not specific to an industry, but is intended to be applicable to the wide spectrum of projects where LSS can be applied. Examples were provided from manufacturing and construction industries in the study. The existing methodologies are framed to target only sustainability initiatives while the presented framework aims to integrate sustainability into any type of improvement initiative. Furthermore, existing methodologies focus almost solely on environmental and economic sustainability, whereas the presented study includes social dimension too. Both academicians and professionals will benefit from the presented framework as it provides a different perspective than what is found in literature enabling broader applications, together with concrete steps and examples demonstrating its implementation, use, and potential benefits.
\end{abstract}

Keywords: Sustainability framework; Sustainability assessment; Green; DMAIC; Lean Six Sigma; Triple Bottom Line 


\section{Introduction}

There continues to be efforts to integrate the concept of sustainability into many aspects of the businesses and operations either due to increasing public interest, regulatory pressures, or corporate social responsibility (Bertels et.al., 2010; Cherrafi et.al., 2016b; Garza-Reyes, 2015; Salem \& Deif, 2017; Sezen \& Cankaya, 2013;Wong \&Wong, 2014). Sustainability is often defined as a balance between the environmental, economic, and social needs of the present as well as future generations. While this triple bottom line approach (Elkington, 1994) captures the three focus areas, the environmental facet of sustainability has been the most addressed component since the introduction of sustainability as a concept at the global stage. This is no different in manufacturing. The term green manufacturing, often used interchangeably with the concept of sustainability, was coined to refer to manufacturing methods and strategies that are mindful of environmental impacts of production and operations (Deif, 2011). Minimizing resource use, waste and pollution are the main goals in achieving green manufacturing. Furthermore, green manufacturing encompasses economic aspects as efficient consumption of resources results in better economic performance (Deif, 2011; Salem\&Deif, 2017). Lean and Six Sigma methods are used more and more in pursuit of green manufacturing (Freitas et.al., 2017).

Lean generates value by improving process flow and lead-time through identifying and reducing waste from the process. Six Sigma, on the other hand, creates value through consistent process output by identifying and reducing variation. Lean Six Sigma (LSS) is a new generation quality improvement tool that combines the two approaches. Fewer defects and rework, lower levels of inventory, faster production, less space requirement, less transportation, less waiting and increased employee motivation are among the benefits of implementing LSS. To this end, there are significant overlaps among LSS and sustainability in terms of intended goals. 
The literature provides many examples of Lean, Green and Six Sigma integration in efforts to improve sustainability performance in manufacturing industries. Research in this field also includes attempts at developing frameworks for seamless integration of the three methods to aid the success of their implementation. The common approach in these frameworks is to progress toward sustainability by identifying a project and assessing its current state of sustainability performance, followed by selecting LSS tools that will help the company increase its sustainability performance such as reducing environmental waste, emissions, energy, or water consumption. While such efforts may be deemed to be in the right direction, implementing sustainability in all facets of business and industry is no longer an option but a necessity and a strategic imperative for company competitiveness (Garza-Reyes-2015). Therefore, a new approach is necessary to accelerate sustainability integration. This can be achieved by embedding sustainability goals into improvement projects such as productivity improvement, quality improvement, improving logistics, streamlining business operations, or reducing costs. The transformation will come in the form of small changes that has a focus on improvement in general but has sustainability as one of its ingredients. Including one or more sustainability goals in every improvement project, not just in projects solely focusing on sustainability, will increase the adoption of sustainability metrics and principles. Given the nature of LSS projects, whether intended or not, almost all produce sustainability improvements as by-product. A comprehensive literature review by Chugani et.al. (2017) documents the green impact of LSS which include conservation of resources, energy savings, and reduction in emissions in a sample of 70 articles from 16 journals. It is the logical next step to systematically embed sustainability goals and metrics into the LSS framework. Such an approach can piggyback on the success and industry embracement of Lean Six Sigma to insure wider adoption. The motivation of this research, 
therefore, is to investigate the extent and effectiveness of the infusion of sustainability measures in LSS improvement projects. In this context, we aim to accomplish the following research objectives: 1) Develop a framework that captures all three dimensions of sustainability and fully embeds sustainability goals in any improvement project using Lean Six Sigma; 2) Present the implementation of this framework in a practical manner; and 3) Provide illustrative examples to demonstrate its application and identify benefits and challenges. The proposed framework is not specific to an industry, but is intended to be applicable to the wide spectrum of projects where LSS can be applied.

\section{Terminology}

\subsection{Sustainability}

The most often cited definition of sustainability is development that meets the needs of the present populations while ensuring to provide the needs of future generations. The statement was originally coined in 1987 following the publication of a report by the United Nations World Commission on Environment and Development (WCED), a commission chaired by Gro Harlem Brundtland, then prime minister of Norway (WCED, 1987), hence the report sometimes being referred to as the Brundtland report. During the years following the report's publication, the concept of sustainable development, later referred to as sustainability, gained international recognition and attention at the highest levels of governance.

Over the next three decades, there have been multitudes of proposed definitions for sustainability. The exact wording and the focus of these definitions vary depending on the context it is used, and the field of science that proposes or embraces the definition (Gatto, 1995; Johnston, 2007; Missimer, 2015; Morelli, 2011; Souza, 2015). The definition adopted in this study is the one based on the triple bottom line (TBL) approach (Elkington, 1994), where 
anthropogenic systems and organizations cannot endure over time should there be a weakening or collapse of any of the three essential elements: environment; economy; and society. It is not the superiority of one, but rather the balance of the three elements that sustains institutions.

The three pillars of TBL, which are now most commonly referred as social, environmental and economic, were defined as 3Ps, People, Planet and Profit, in the original TBL study (Elkington, 1994). The social aspect (People) focuses on the needs of the individual and the communities, and includes areas such as standards of living, resources for education and jobs, empowerment, and health and safety; the environmental aspect (Planet) examines activities and practices related to the use of natural resources, energy consumption, ecological health, and pollution; and finally, the economic aspect (Profit) covers strategies that promote economic growth and profits, cost savings, and research and development (Alhaddi, 2015). As discussed previously, most sustainability efforts capture environmental and economic aspects, and the social aspect of sustainability is the least considered one (Verrier et.al., 2016).

Beyond the definition, the main implementation challenge of sustainability studies is the question of assessment (Cinelli et.al., 2014; Khalili et.al., 2015; Santoyo-Castelazo \& Azapagic, 2014; Waas et.al., 2014). While there are certain tools such as Life Cycle Assessment (LCA), a comprehensive tool that captures all three pillars of sustainability is lacking (Finkbeiner et al. 2010). Sustainability studies also lack a structured framework due to the number of diverse topics that fall under the same term (Cinelli et.al., 2014; Garza-Reyes, 2015). Therefore, while it is commonly agreed that the concept of sustainability needs to be more integrated into the mindset and day-to-day operations of institutions, the means in which that is to come about is still in its infancy and needs further work. The study described herein is an attempt to bring a structured approach that will facilitate integration and adoption of sustainability in that regard. 


\subsection{Lean and Six Sigma}

Lean aims to maximize customer satisfaction through eliminating waste from the organization's value stream. The seven forms of waste identified in Lean culture are inventory, movement, motion, rework, waiting, over-processing, and overproduction. The definitions of these wastes are fairly standard and can be found in the relevant literature. Skills is another form of waste that was identified later. It occurs when people's talents, capabilities and knowledge are underutilized.

Six Sigma is a data driven methodology which focuses on reducing variation. In statistical terms, Six Sigma implies process output with no more than 3.4 defects in every million opportunities. Most Six Sigma implementations follow the DMAIC cycle (acronym for Define, Measure, Analyze, Improve, and Control). DMAIC provides a structured approach to improvement activities and is a proven framework in gaining significant improvements in performance.

Improvements achieved through either method also impact sustainability. A comprehensive literature review by Cherrafi et.al. (2016) lists improved employee moral and commitment, improved working conditions, better use of human resources, improved employee awareness about environmental, health and safety issues among the impacts of LSS efforts on social sustainability. Impacts on economic sustainability include improved profits, increased process and equipment reliability, and meeting customer expectations, while impacts on environmental sustainability consist of improved resource efficiency, reduced environmental impacts and reduced risks for non-compliance. Based on these premises, our study proposes a different perspective on the use of LSS in sustainability. The current practices start with a sustainability goal and utilizes LSS in achieving these goals. We suggest looking at the problem from an 
opposite lens, and aim to redefine the lean six sigma cycle to include sustainability goals as part of the improvement effort at all times.

\section{Integration of Lean, Six Sigma and Sustainability - Current State}

Literature supports the positive relationship between Lean and environmental sustainability (Garza-Reyes et.al., 2015; Gupta et.al., 2018; Hartini \& Ciptomulyono, 2015; Verrier et.al., 2016). Improving mass and energy flow in automotive manufacturing operations using Kaizen approach (Pampanelli et.al., 2014), optimizing the use of natural resources and production output in a secondary tissue paper and board mill with an emphasis on Kaizen and 5S (Vais et.al., 2006), improving energy efficiency and reducing environmental impacts in foundry operations using VSM and 5S (Torielli et.al., 2011), and improving environmental performance of road transport operations through VSM (Garza-Reyes et.al., 2016) are some examples in which lean methods were utilized to improve environmental sustainability. Furthermore, organizations including U.S. Environmental Protection Agency (EPA) and the European Commission advocate use of Lean in achieving environmental sustainability (EPA 2006, European Commission 2014). After its initial report titled "The Lean and Environment Toolkit" (2006, revised in 2007), EPA published three more lean toolkits with specific focus areas, which are chemical waste (2009), energy efficiency and greenhouse reduction (2011), and water use (2011).

While there is considerable literature on integration of Lean and sustainability, or Lean and Green as called in manufacturing, solely Six Sigma and sustainability-focused work are not widespread. Among the few, the DMAIC process is used to reduce environmental impacts of discharging the produced water in oil fields by removing contaminants (Al-Shamkhani \& Elshennawy, 2013). Calia et.al. (2009) analyzed a performance of a pollution prevention program in a multinational corporation before and after Six Sigma implementation and showed 
that the implementation of Six Sigma significantly improved the program performance in terms of the total number of projects completed and the total tones of pollution prevented. Lee et.al. (2014) developed a Six Sigma based energy management planning procedure to improve energy efficiency, reduce cost and conserve natural resources. The procedure was based on energy audits that the authors performed as part of their Industrial Assessment Center (IAC) activities, and includes sample action plans for energy savings, models to estimate savings, and preventive maintenance plans to deploy during the control phase.

The studies on the integration of all three methods, Lean, Six Sigma and sustainability, is further scarce (Freitas et.al., 2017), and this is in line with the conclusions of the few studies that explored their nexus (Cherrafi et.al., 2016a; Garza-Reyes, 2015; Kumar et.al., 2015). GarzaReyes (2015) developed a conceptual model to integrate Lean, Six Sigma and Green concepts using DMAIC cycle, and provided a list of LSS tools that can be used in this implementation. Kumar et.al. (2015) studied the barriers, enablers and critical success factors that are important to identify for successful implementation of an integrated model. Human resources and management were the top two ranked critical success factors. Enablers such as providing training, using a rewarding system, management commitment and leadership, availability of funding and resources were reported the most important. Lack of technical tools for environmental management, resistance to change, both from the producer and the supplier, and inadequate human resources in terms of skills and knowledge in green concepts were listed as the obstacles that need the most attention. Their work, however, does not provide an implementation framework. Banawi and Bilec (2014) developed a model to integrate Lean, Six Sigma and Green to reduce waste associated with construction. While this model is tested in a real environment, it uses limited number of LSS tools, and only analyze and improve phases of the DMAIC cycle is 
considered in the model. Finally, Cherrafi et.al. (2016a) presented a comprehensive integration model which was tested in four different industries. Their model, similar to the others, aims to offer framework for projects that have green scope only.

The following conclusions were drawn from existing studies:

- The DMAIC and PDCA approaches, Pareto Analysis, cause and effect matrix, VSM, ANOVA, statistical process control (SPC) and failure mode and effects analysis (FMEA) are among the frequently referred LSS tools and methods for achieving sustainability goals in these studies.

- The combination of Lean and Green seems logical as their objectives (waste reduction) are compatible.

- Lean Six Sigma brings a structured approach and data driven analysis to eliminate or reduce the sources of variation and waste.

- The environmental performance of sustainability is almost the only dimension of sustainability addressed in all studies. Excessive use of resources (water, power), pollution, and gas emissions are the most frequently tackled environmental items.

- Most studies consider economic sustainability as an outcome of improving environmental sustainability performance.

- Very few discuss social aspect.

- The goal in integration is to apply LSS methodology in sustainability projects to improve sustainability performance.

Literature suggests that use of LSS in implementing sustainability produces positive outcomes on environmental and economic performance (Antony et.al., 2017; Chugani et.al., 2017). However, the implementation is not without challenges. Weak organizational support, lack of 
funds for green projects, lack of organizational resources and uncertain benefits, lack of implementation strategies, tools and practices are frequently cited barriers for sustainability studies and sustainability studies with LSS approach (Bhanot et.al., 2015; Cherrafi et.al., 2016b; Cherrafi et.al., 2017; Kumar et.al., 2015; Mittal\&Sangwan, 2014). Embedding sustainability goals in smaller scale in any LSS project as an alternative to large projects that has sustainability scope only can aid in overcoming these hurdles.

Moreover, the current focus is confined to the environmental and economic dimensions of the triple bottom line (TBL), but tends to overlook the social dimension. This approach falls short in providing effective and long-term sustainability changes. Embracing all three dimensions of TBL is necessary for all industries and fields including manufacturing for complete implementation of sustainability. In addition to its high-energy consumption, the manufacturing sector also employs $23 \%$ of the worldwide total employment (Bonvoisin et.al., 2017). The attention needed on working conditions and labor practices alone requires social dimension to be included in sustainability efforts in manufacturing. The proposed framework provides guidelines on how to address all three dimensions of TBL in integrating sustainability into everyday operations.

\section{Embedding Sustainability into Lean, Six Sigma Efforts}

\subsection{The Model}

Lean Six Sigma has become the most prevalently used approach to process improvement. It has been adopted across all industries, not just manufacturing, as a successful methodology that focuses on four key issues: quality, productivity, cost and profitability (Evan\&Lindsay, 2015). The five-step DMAIC process provides a structured approach that incorporates a wide range of LSS tools in a goal-oriented manner in management and execution of improvement projects. As indicated in Table 1, each step in the DMAIC process has a particular set of tasks and associated 
tools that start from the definition of the problem to ensuring that the improvements are sustained (Ismyrlis\&Moschidis, 2013; Miguel P.A.C. et.al., 2012; Uluskan, 2016; Uluskan, 2017) .

Table 1 Steps of the DMAIC process together with commonly used LSS tools

\begin{tabular}{|c|c|c|c|c|}
\hline & & ANALYZE & $\mathbf{E}$ & $\mathrm{DL}$ \\
\hline \multicolumn{5}{|c|}{ TASKS } \\
\hline $\begin{array}{l}\text { - Develop project } \\
\text { charter including } \\
\text { problem statement, } \\
\text { project goals, } \\
\text { critical-to-quality } \\
\text { requirements, team } \\
\text { members and } \\
\text { responsibilities, and } \\
\text { resources } \\
\text { - Map the process }\end{array}$ & $\begin{array}{l}\text { - Establish } \\
\text { performance } \\
\text { metrics } \\
\text { - Validate } \\
\text { measurement } \\
\text { system } \\
\text { - Collect data } \\
\text { - Determine } \\
\text { process } \\
\text { baseline }\end{array}$ & $\begin{array}{l}\text { - Analyze data to } \\
\text { identify sources } \\
\text { of } \\
\text { variation/waste } \\
\text { - Examine the } \\
\text { process to } \\
\text { identify root } \\
\text { causes }\end{array}$ & $\begin{array}{l}\text { - Develop and } \\
\text { evaluate } \\
\text { solutions } \\
\text { - Implement } \\
\text { selected } \\
\text { alternatives }\end{array}$ & $\begin{array}{l}\text { - Verify } \\
\text { improvements } \\
\text { - Develop } \\
\text { standards and } \\
\text { procedures } \\
\text { - Develop and } \\
\text { implement } \\
\text { control plans }\end{array}$ \\
\hline \multicolumn{5}{|c|}{ Commonly used LSS Tools } \\
\hline $\begin{array}{l}\text { - Project Charter } \\
\text { - Process Map } \\
\text { - SIPOC } \\
\text { - Voice of the } \\
\text { Customer analysis } \\
\text { - Stakeholder } \\
\text { analysis } \\
\text { - Kano analysis } \\
\text { - Critical-to-Quality } \\
\text { tree } \\
\text { - House of Quality }\end{array}$ & $\begin{array}{l}\text { - Key } \\
\text { Performance } \\
\text { Indicators } \\
\text { - Value Stream } \\
\text { Map } \\
\text { - Check sheets } \\
\text { - Histogram } \\
\text { - Run chart } \\
\text { - Process } \\
\text { Capability } \\
\text { - Measurement } \\
\text { System } \\
\text { Analysis }\end{array}$ & $\begin{array}{l}\text { - Spaghetti } \\
\text { diagrams } \\
\text { - Cause and } \\
\text { Effect diagram } \\
\text { - Pareto chart } \\
\text { - } 5 \text { Whys } \\
\text { - Hypothesis } \\
\text { Testing } \\
\text { - ANOVA } \\
\text { - Scatter Plots } \\
\text { - Regression } \\
\text { analysis }\end{array}$ & $\begin{array}{l}\text { - Prioritization } \\
\text { Matrix } \\
\text { - Risk Analysis } \\
\text { - Mistake } \\
\text { Proofing } \\
\text { - Visual } \\
\text { Management } \\
\text { - Design of } \\
\text { Experiments } \\
\text { - Failure Mode } \\
\text { Effects } \\
\text { Analysis } \\
\text { - Standardization }\end{array}$ & $\begin{array}{l}\text { - Control } \\
\text { Charts } \\
\text { - Dashboards } \\
\text { - Audit plans } \\
\text { - Performance } \\
\text { Management }\end{array}$ \\
\hline
\end{tabular}

Drawing on the significant gains achieved in process improvement through LSS and its wide adoption across all industries, integration of sustainability in the DMAIC framework can be a remedy against lack of implementation strategies, and it will provide tools and practices for 
achieving sustainability goals and encourage wider adoption of sustainability principles into business practices. This integration starts in the define phase by identifying sustainability opportunities that can be tied to an improvement project and continues with defining associated goals and metrics that will allow follow-through in the subsequent phases to achieve the desired sustainability outcomes. Table 2 outlines the main tasks to carry out in each step to ensure sustainability efforts are fully embedded in the improvement project and that they are aligned with the rest of the project goals and efforts. While three phases of the DMAIC process includes additional steps for embedding sustainability into the project, the remaining steps, analyze and control, are carried out in a traditional manner.

Table 2 Steps of the DMAIC process and associated tasks as a means to integrate sustainability

\begin{tabular}{|l|l|}
\hline STEP & TASK \\
\hline Define & $\begin{array}{l}\text { Identify sustainability indicators and develop one (or more) sustainability goals that } \\
\text { can be linked to the current project }\end{array}$ \\
\hline Measure & Develop sustainability metrics for the goals included in the Define step \\
\hline Analyze & Follow traditional A \\
\hline Improve & $\begin{array}{l}\text { Perform cost-benefit comparison of sustainability solutions if they might impact the } \\
\text { expected project gains negatively }\end{array}$ \\
\hline Control & Follow traditional C \\
\hline
\end{tabular}

The most important task in integrating sustainability in any type of improvement project is to create the link between sustainability goals of the company and the goals of the improvement project. For this to be effective and to ensure successful alignment of the goals, it is vital to determine the sustainability needs and priorities of the company. Therefore, a preliminary step for any company to undertake a LSS project with sustainability elements is to perform a sustainability assessment to identify and prioritize sustainability targets for the company with respect to environmental, social and economic aspects. Such an assessment involves reviewing 
and evaluating the company's current sustainability performance, and generates a documentation of the needs and priorities of the company for the improvement teams to use as a guideline when developing sustainability goals and metrics for their projects.

An Importance-Impact-Implementation analysis developed for sustainability assessment is described in the following section. Table 3 lists the common sustainability indicators complied from literature (Cherrafi et.al., 2016a; Cherrafi et.al., 2016b; Deif, 2011; GRI, 2011; Freitas et.al., 2017; Resta et.al., 2016; Sutherland et.al., 2016; UNEP, 2016). This list can be modified depending on the priorities of the company performing the assessment. For example, EPA's database of sustainability indicators and indicies (DOSII) that contains more than 2,500 indicators and indices can be used to tailor this table with indicators that are more relevant to specific sustainability interests (EPA, 2014). Table 4 shows the assessment matrix used in this approach and presents a few numerical examples. In real-life implementation, a company would assess all of the sustainability indicators included in the assessment matrix.

Table 3 Common sustainability indicators selected from literature

\begin{tabular}{|l|l|l|}
\hline \multicolumn{3}{|c|}{ Sustainability Dimension/Indicator } \\
\hline Environmental & Social & Economic \\
\hline $\begin{array}{l}\text { Energy } \\
\text { efficiency/consumption }\end{array}$ & Health and Safety & Consumption patterns \\
\hline $\begin{array}{l}\text { Efficient Use of Natural } \\
\text { Resources }\end{array}$ & Standard of Living & Distribution of wealth \\
\hline $\begin{array}{l}\text { Pollution Prevention - } \\
\text { emissions to air }\end{array}$ & Education and skills & $\begin{array}{l}\text { Research and development (New } \\
\text { processes and products, technology) }\end{array}$ \\
\hline $\begin{array}{l}\text { Pollution Prevention - } \\
\text { emissions to water }\end{array}$ & $\begin{array}{l}\text { Employment (retention, } \\
\text { loss of talent) }\end{array}$ & Revenue generation \\
\hline $\begin{array}{l}\text { Pollution Prevention - } \\
\text { emissions to land }\end{array}$ & Community & Smart Growth \\
\hline Waste Management & Diversity and Equity & \\
\hline Efficient use of materials & Identity & \\
\hline
\end{tabular}




\section{Sustainability importance-impact-implementation analysis}

First, sustainability indicators are ranked based on importance, impact and implementation criteria as shown in the assessment matrix in Table 4. Importance ranking is done according to the relevance of the indicator to the company operations. A score of 5 in the importance category indicates that the item is significantly relevant to business operations. Impact ranking evaluates the gains expected. A score of 5 in the impact category denotes that the business will realize significant gains if improvements are achieved. Finally, implementation ranking scores the difficulty of implementation. A score of 5 in the implementation category shows that the item is easy to tackle. For example, the scoring for the indicator energy efficiency/consumption in Table 4 reveals that this indicator is very relevant to company operations (5) and if improvements are achieved in this category significant gains are expected (5). Nevertheless, the implementation of energy related activities are difficult (1). On the other hand, the indicator research and development shows that while the company could gain from research and development (3), its relevance to business operations are not high (2). However, the implementation of research and development related activates is not challenging (4).

Another example is where an indicator might be very important to the company and also be very difficult to implement, but not much gain could be achieved. The indicator with scorings $(5,1,1)$ would fall into this case. Another case is where the indicator may not be important yet could be fairly straightforward to implement and decent gains can be expected. The indicators with scorings $(1,3,4)$ would represent this case. Education and skills and diversity and equity in Table 4 represent such scenarios. 
Table 4 An example Importance-Impact-Implementation analysis for sustainability assessment

\begin{tabular}{|c|c|c|c|c|}
\hline $\begin{array}{l}\text { Sustainability } \\
\text { Dimension }\end{array}$ & Indicators & $\begin{array}{c}\text { Importance } \\
\text { (1=least } \\
\text { important; } \\
\text { 5-most } \\
\text { important) }\end{array}$ & $\begin{array}{l}\text { Impact } \\
(1=\text { least } \\
\text { impact; } \\
5=\text { most } \\
\text { impact }\end{array}$ & $\begin{array}{l}\text { Implementation } \\
(1=\text { most difficult; } \\
5=\text { least difficult })\end{array}$ \\
\hline \multirow{7}{*}{ Environmental } & Energy efficiency/consumption & 5 & 5 & 1 \\
\hline & $\begin{array}{l}\text { Efficient Use of Natural } \\
\text { Resources }\end{array}$ & 2 & 1 & 1 \\
\hline & $\begin{array}{l}\text { Pollution Prevention - emissions } \\
\text { to air }\end{array}$ & & & \\
\hline & $\begin{array}{l}\text { Pollution Prevention - emissions } \\
\text { to water }\end{array}$ & & & \\
\hline & $\begin{array}{l}\text { Pollution Prevention - emissions } \\
\text { to land }\end{array}$ & & & \\
\hline & Waste Management & & & \\
\hline & Efficient use of materials & & & \\
\hline \multirow{8}{*}{ Social } & Health and Safety & & & \\
\hline & Standard of Living & & & \\
\hline & Education and skills & 5 & 1 & 1 \\
\hline & $\begin{array}{l}\text { Employment } \\
\text { (retention, loss of talent) }\end{array}$ & 5 & 5 & 3 \\
\hline & Community & & & \\
\hline & Diversity and Equity & 1 & 3 & 4 \\
\hline & Identity & & & \\
\hline & Inclusion & & & \\
\hline \multirow{5}{*}{ Economic } & Consumption patterns & & & \\
\hline & Distribution of wealth & & & \\
\hline & $\begin{array}{l}\text { Research and development } \\
\text { (New processes and products, } \\
\text { technology) }\end{array}$ & 2 & 3 & 4 \\
\hline & Revenue generation & & & \\
\hline & Smart Growth & & & \\
\hline
\end{tabular}

After sustainability assessment matrix is completed, a visual mapping such as the one shown in Figure 1 is developed to help improvement teams in their selection of sustainability indicators in their projects. The $x$-axis in this chart shows the importance of the indicator, and the $y$-axis shows impact. The size of the circles represents the difficulty in implementation. The selection of 
indicators will depend on the nature of the improvement project, however, as a rule of thumb, the teams should focus on larger circles first, and simultaneously consider the items in higher priority regions.

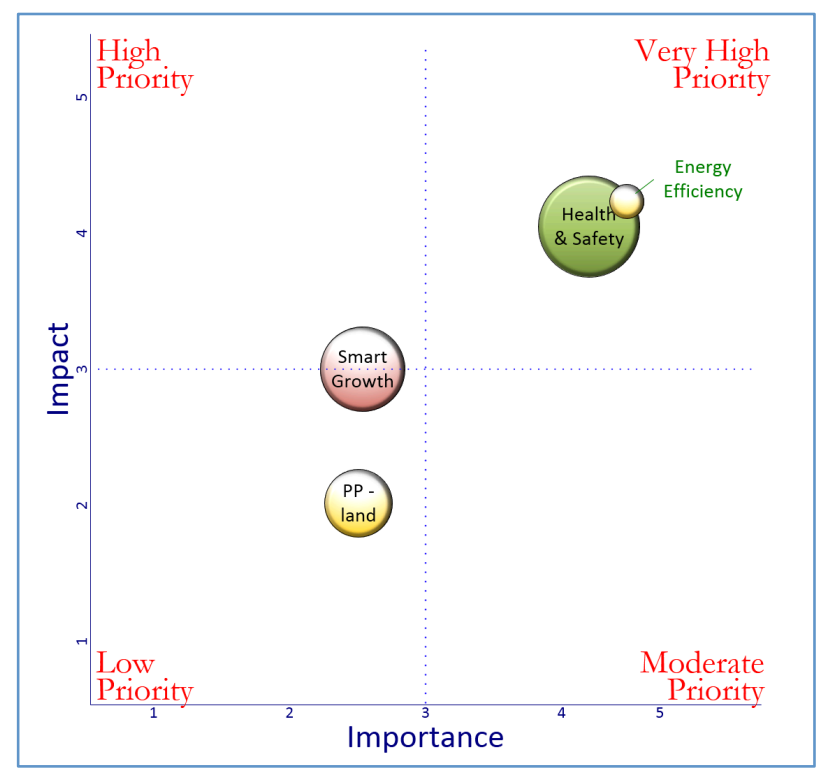

Figure 1 Sustainability indicators priority chart

Define \& Measure:

Every improvement project following the DMAIC approach starts with developing a project charter. The project charter is a written document that provides a consolidated summary of the project typically including problem definition, background and purpose, scope, team composition, timeline, performance measures and deliverables. The project charter is the roadmap for the project and keeps teams focused on generating results that are aligned with the project goals. Therefore, define phase is a vital step in embedding sustainability goals into the improvement activities and into the project charter.

The first activity in integrating sustainability is to select sustainability indicators that can be linked to the project goal(s). This is where the visual mapping of sustainability assessment (Figure 1) will steer the efforts.

After the sustainability indictor(s) is selected, sustainability goals and metrics have to be 
added to the project. In some cases sustainability goals will already be in alignment with the project goals. In other words, the LSS project goal can be a sustainability goal even if it is not labeled as one. In other cases, additional goals will be added to the project to cover a sustainability aspect.

For developing sustainability goals and metrics, we adopted Donabedian's Triad of quality indicators for examining health services and evaluating quality of health care (Donabedian, 1966). In his widely accepted healthcare measurement model, Donabedian suggests three measurement categories to represent different characteristics of healthcare services: structure, process and outcomes. The structure measures evaluate the adequacy of the environment and include items such as facilities, equipment, procedures, human resources, and leadership. The process measures assess the quality of activities, i.e. whether they are performed satisfactorily, such as the level of compliance to existing policies, accuracy of diagnosis, etc. Finally, the outcomes measures evaluate the results such as patient experience, complication rates, and mortality rate. An example structure, process, outcome measurement of healthcare services involving CT-scan would be having proper CT-scan equipment available (structure); performing CT-scan to all patients arrive with a head trauma (process); and re-admission rate of patients with head injuries who received CT-scans (outcome). When CT-scan related quality issues are studied, the findings might show that the hospital has the proper equipment, but the employees may not be following the procedures. In such cases the improvement focus will be on the process. Alternatively, the study result might indicate that the equipment is available, and the policies and procedures are followed, but the re-admission rates are high. This will steer the improvement team to other parts of the system for further investigation. Together these three measures help observe quality issues in a more comprehensive manner and guide the improvement process. 
This comprehensive view inherit in the Donabedian framework can help overcome the issues in implementation of sustainability including the almost sole focus on environmental and economic aspects and overlook on social sustainability. Assessing the success of implementation not only using the outcome measures, but also by evaluating the structure and process outcomes will also ensure capturing potential issues that might hinder the long-term survival of sustainability improvements achieved.

To demonstrate the integration of sustainability indicators into improvement projects and the use of structure-process-outcomes measures approach to develop sustainability goals and metrics, we selected four studies from the literature that follow DMAIC approach for process improvement. The studies were implemented in different industry or settings, namely healthcare, manufacturing, and construction. The second row in each section of Table 5 shows the project goals and metrics as reported in these studies, the four columns below the second row show the proposed sustainability indicator(s) linked to the project, and the example structure, process and outcome measures that could be used to evaluate the sustainability performance.

As discussed above, the structure-process-outcomes measures approach helps to identify the areas for improvement in a more comprehensive manner. For example, in the hospital discharge case listed in Table 5, the improvement in sustainability performance may come from establishing more patient-centered policies if the structure measure happens to be the weak area. If the patient-centered policies are already in place, but the documentation process described under process measure is not followed consistently, then the focus would be on how to ensure staff's completion of the community support sections in the discharge process. Finally, if the problem area is the outcomes, this means that the hospital has patient centered policies, and the staff follows the prescribed discharge process by documenting the available community support 
services, nevertheless some of the patients do not receive this information upon their discharge from the hospital. In this case, an investigation to discover the breakage points between the documentation and the actual discharge should be performed. This comprehensive assessment approach not only helps linking sustainability goals into the improvement projects, but also ensures the measures exist to guide how to achieve the goals.

Table 5 Goals and Outcomes Mapping - Examples

Study 1: "Improving the Hospital Discharge Process with Six Sigma Methods", (Allen et.al., 2010)

Project Goal: Streamline the hospital discharge process

Measurable Goals: Reduce average discharge time; Reduce missing chart data

\begin{tabular}{l|l|l|l}
$\begin{array}{l}\text { Sustainability } \\
\text { Indicator }\end{array}$ & $\begin{array}{l}\text { Structure } \\
\text { (Resources) }\end{array}$ & $\begin{array}{l}\text { Process } \\
\text { (Delivery) }\end{array}$ & $\begin{array}{l}\text { Outcomes } \\
\text { (Results) }\end{array}$ \\
\hline $\begin{array}{l}\text {-Community } \\
\text { (social) }\end{array}$ & $\begin{array}{l}\text { Patient-centered } \\
\text { policies }\end{array}$ & $\begin{array}{l}\text {-Documentation of } \\
\text { discharge patients' } \\
\text { community support }\end{array}$ & $\begin{array}{l}\text {-Percentage of discharge } \\
\text { patients provided with } \\
\text { information on community } \\
\text { based support resources }\end{array}$ \\
\hline
\end{tabular}

Study 2: "Applying Lean Six Sigma to Reduce Linen Loss in an Acute Care Hospital", (Furterer, 2011)

Project Goal: Evaluate the laundry/linen distribution operations to identify improvement opportunities

Measurable Goals: Reduce the amount of replacement linen; Reduce linen loss

\begin{tabular}{|c|c|c|c|}
\hline $\begin{array}{l}\text { Sustainability } \\
\text { Indicator }\end{array}$ & $\begin{array}{l}\text { Structure } \\
\text { (Resources) }\end{array}$ & $\begin{array}{l}\text { Process } \\
\text { (Delivery) }\end{array}$ & $\begin{array}{l}\text { Outcomes } \\
\text { (Results) }\end{array}$ \\
\hline $\begin{array}{l}\text { •Efficient use of } \\
\text { materials } \\
\text { (environmental) } \\
\text { •Education and } \\
\text { skills (social) }\end{array}$ & $\begin{array}{l}\text {-Materials (linen) } \\
\text { management } \\
\text { system } \\
\text {-Materials } \\
\text { management } \\
\text { personnel }\end{array}$ & $\begin{array}{l}\text { - Use of dirty linen } \\
\text { containers } \\
\text { - Visual displays of linen } \\
\text { policies and procedures }\end{array}$ & $\begin{array}{l}\text {-Percentage of linens } \\
\text { disposed incorrectly } \\
\text {-Percentage of employees } \\
\text { trained in linen usage } \\
\text { policies and procedures }\end{array}$ \\
\hline
\end{tabular}


Table 5 (cont'd) Goals and Outcomes Mapping - Examples

Study 3: "A Six Sigma and DMAIC Application for the Reduction of Defects in a Rubber Gloves Manufacturing Process", (Jirasukpraset et. al., 2013)

Project Goal: Improve product quality and increase customer satisfaction for rubber manufacturing organization

Measurable Goals: Reduce defect percentage on "medium” size rubber gloves; Reduce the number of defects for two types of defects (leaking and dirty)

\begin{tabular}{|c|c|c|c|}
\hline $\begin{array}{l}\text { Sustainability } \\
\text { Indicator }\end{array}$ & $\begin{array}{l}\text { Structure } \\
\text { (Resources) }\end{array}$ & $\begin{array}{l}\text { Process } \\
\text { (Delivery) }\end{array}$ & $\begin{array}{l}\text { Outcomes } \\
\text { (Results) }\end{array}$ \\
\hline $\begin{array}{l}\cdot \text { Health and Safety } \\
\text { (social) } \\
\text {-Pollution prevention } \\
\text { - emission to water } \\
\text { (environmental) } \\
\text {-Efficient use of } \\
\text { natural resources } \\
\text { (environmental) } \\
\text {-Energy efficiency } \\
\text { (environmental) }\end{array}$ & $\begin{array}{l}\text {-Company policies } \\
\text { on contamination } \\
\text { (dusts, fumes, } \\
\text { chemical } \\
\text { byproducts) in work } \\
\text { environment } \\
\text {-Wastewater } \\
\text { management system } \\
\text {-Water and energy } \\
\text { use monitoring } \\
\text { system }\end{array}$ & $\begin{array}{l}\text {-Periodic health } \\
\text { check-ups for } \\
\text { workers } \\
\text { • Following } \\
\text { wastewater } \\
\text { treatment practices } \\
\text { - Following energy } \\
\text { and water } \\
\text { conservation } \\
\text { practices }\end{array}$ & $\begin{array}{l}\text { - Number of workers with } \\
\text { cancers due to } \\
\text { occupational exposure } \\
\text { - Levels of hazardous } \\
\text { chemical in treated } \\
\text { wastewater } \\
\text { - Amount of water, energy } \\
\text { usage }\end{array}$ \\
\hline
\end{tabular}

Study 4: "Reducing Welding Defects in Turnaround Projects: A Lean Six Sigma Case Study", (Anderson\&Kovach, 2014)

Project Goal: Reduce unexpected downtime in turnaround projects

Measurable Goals: Reduce the average weld repair rate

\begin{tabular}{|c|c|c|c|}
\hline $\begin{array}{l}\text { Sustainability } \\
\text { Indicator }\end{array}$ & $\begin{array}{l}\text { Structure } \\
\text { (Resources) }\end{array}$ & $\begin{array}{l}\text { Process } \\
\text { (Delivery) }\end{array}$ & $\begin{array}{l}\text { Outcomes } \\
\text { (Results) }\end{array}$ \\
\hline $\begin{array}{l}\cdot \text { Health and Safety } \\
\text { (social) } \\
\cdot \begin{array}{l}\text { Education and skills } \\
\text { (social) }\end{array} \\
\text {-Pollution prevention } \\
\text { - emission to air } \\
\text { (environmental) } \\
\text {-Energy efficiency } \\
\text { (environmental) }\end{array}$ & $\begin{array}{l}\text {-Company policies } \\
\text { on hazardous } \\
\text { materials } \\
\text { • Energy use } \\
\text { monitoring system }\end{array}$ & $\begin{array}{l}\text {-Documentation of } \\
\text { health effects of } \\
\text { welding material } \\
\text { (gases and fumes) } \\
\text {-Percentage of welders } \\
\text { that are ranked by } \\
\text { American Welding } \\
\text { Society classifications } \\
\text {-Energy conservation } \\
\text { practices }\end{array}$ & $\begin{array}{l}\text { - Percentage of substitute } \\
\text { material used to } \\
\text { minimize the hazards } \\
\text { of welding material } \\
\text {-Percentage of welders } \\
\text { trained to improve skill } \\
\text { levels } \\
\text { - Amount of energy } \\
\text { usage }\end{array}$ \\
\hline
\end{tabular}


The measure phase also involves creating detailed process maps to understand how it is currently performed and to guide the data collection process for the metrics identified. In some cases the detailed process map has to be generated first to be able to fully define the process metrics. In others cases, the process metrics can be determined based on the knowledge of the process and the problem that the team wants to address before a detailed map is generated. In either approach, the sustainability indictors and goals have to be added to the detailed process map so that they are visible and recognizable to the team members. Value stream maps (VSM) is one of the most commonly used visual representation of a process in LSS implementation. The VSM shows the specific activities occurring in the process. It includes process steps, flow of materials and information, inventory points, shipments, and removal of materials. The VSM also includes data about the process step such as cycle time, set up time, uptime, lot size, and the number of operators. It is especially useful in identifying waste, also known as non-value added activities, in the process. The sustainability indicators can be added to the VSM in three ways: 1) as a kaizen event, 2) in the timeline, and 3) as part of the data box. Figure 2 shows a sample VSM with the possible locations for integration of sustainability indicators and goals. In this VSM, the kazien event focuses on energy usage, while the water usage is monitored throughout the process in the timeline and the number of trained employees are captured for each process step in the data box. In the case of traditional process maps, the sustainability indicator and goals can be added by color-coding the process blocks. 


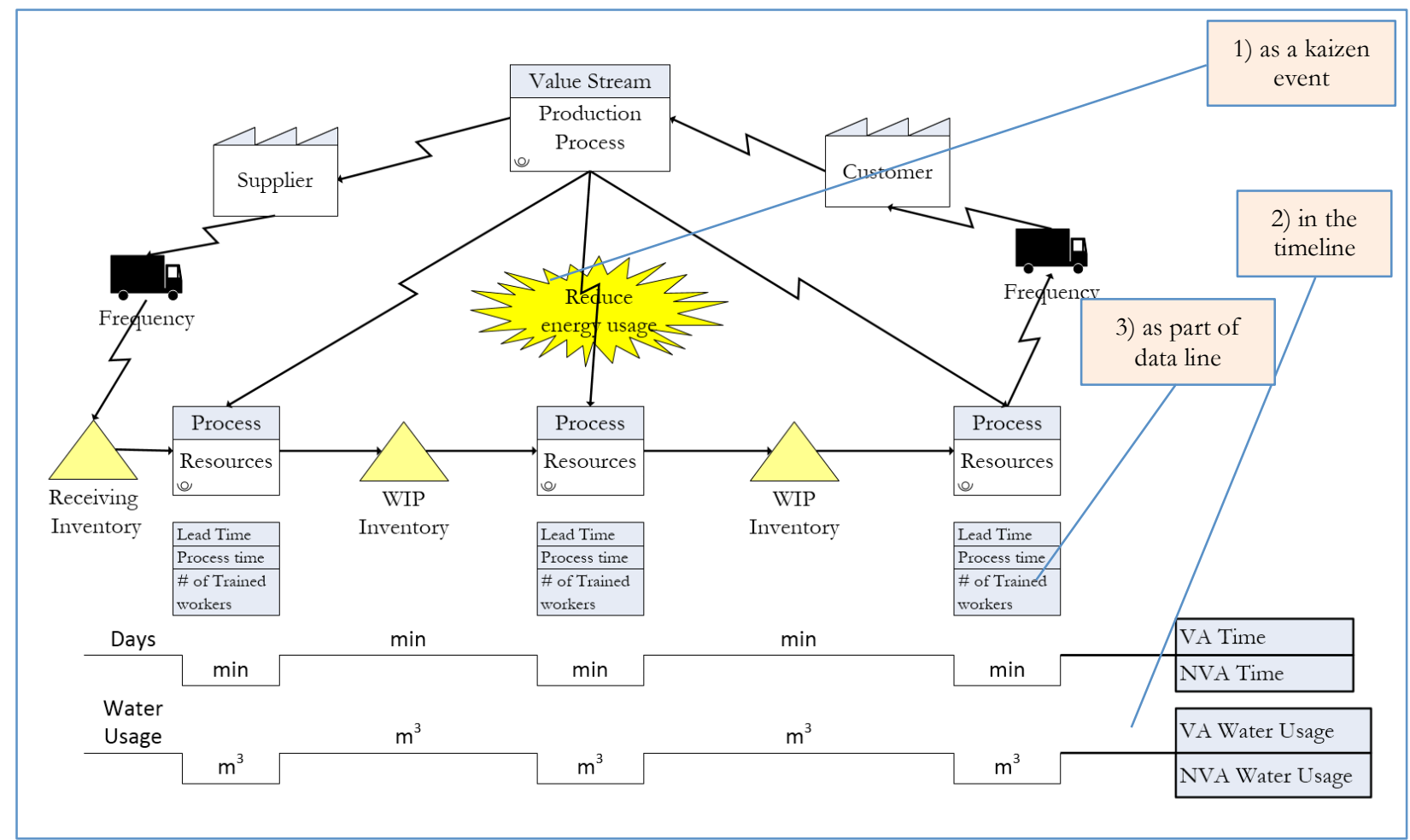

Figure 2 Value Stream Map - Sustainability adoption

Analyze:

After sustainability mapping into the improvement project is complete, the analyze phase is conducted in usual manner to identify the sources of variation and waste, and to examine the process to identify root causes. Process analysis and data analysis (statistical and graphical) can be done to identify process points with opportunities for sustainability improvement with respect to the structure-process-outcomes metrics defined in the previous steps.

\section{Improve:}

The final non-traditional step in embedding sustainability into LSS is to perform cost-benefit comparison of sustainability solutions. This step is performed only if the recommended solutions to improve the sustainability metrics deteriorate the expected impact of the LSS project has it been conducted as a process improvement activity alone. In the cases for which the 
recommended sustainability solutions require financial investment such as installing a waste management system to achieve pollution prevention, one can argue that sustainability efforts will always negatively impact the project outcomes. However, as noted before, sustainability is now a strategic imperative for company competitiveness, therefore, sustainability benefit assessment should not be based on financial numbers alone.

The most commonly listed benefits of sustainability to businesses are lower operating cost and increased profitability, employee engagement and satisfaction, public appeal and market opportunity, talent acquisition and retention, better management of business risks, access to capital and investors, and tax incentives (UNEP, 2016). A comprehensive cost-benefit comparison of sustainability solutions would include items such as the ones shown in Figure 3.

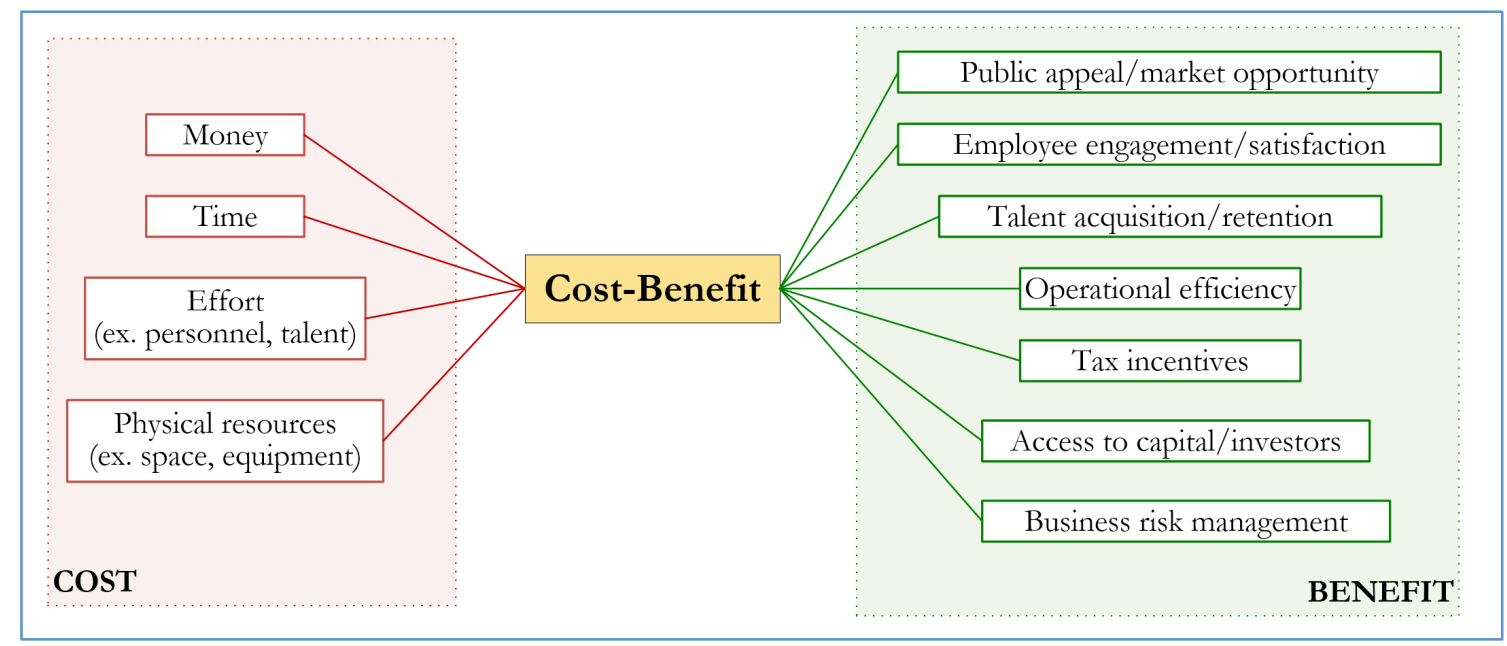

Figure 3 Sustainability cost-benefit elements

To evaluate a particular solution a bar chart can be generated by ranking each cost and benefit item on a 1 to 5 scale where 5 shows the most impact. Then, a decision on whether or not to implement the recommended solution can be made based on the expected gains and losses. The example bar chart, shown in Figure 4, was created for a sustainability solution generated for the rubber glove manufacturing case listed in Table 5. The recommended solution is repairing 
leaks and reducing intake in temperature of compressed air system through preventive maintenance and process equipment modification. The expected benefits are reduction in electricity usage, compressed air and GHG emissions.

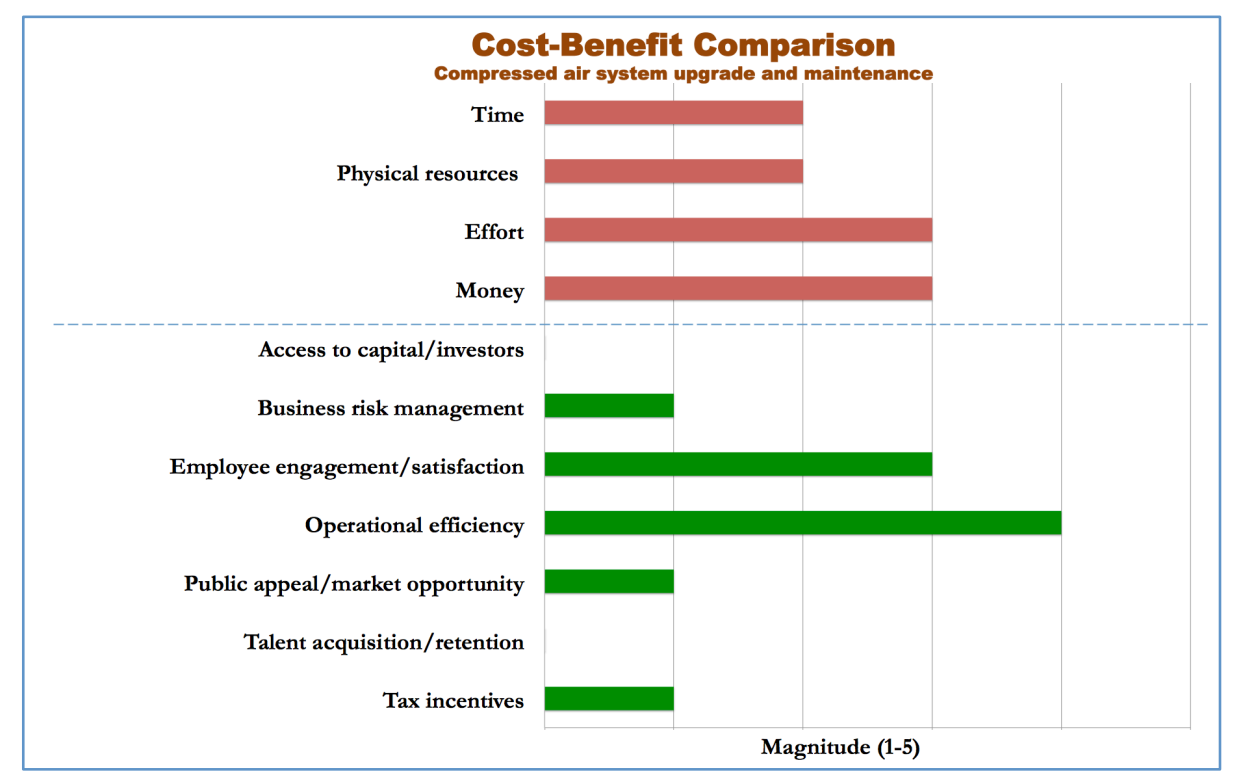

Figure 4 Sustainability Solution Assessment

\section{Control:}

Control phase focuses on maintaining the gains of improvement, and involves developing and executing control plans. Statistical process control methods, standard operating procedures, visual process control tools, and training plans are most commonly used tools in this phase and can be applied to sustainability activities completed in the previous phases. The control for the compressed air system solution discussed above, for example, may involve development of maintenance and training manuals for the operators to perform timely and adequate maintenance of equipment.

\subsection{Essentials and Insights of the Model}

As it can be seen in the examples in Table 5, environmental sustainability naturally aligns with improvement activities in good-producing industries, in this case manufacturing and 
construction. Elimination of defects leads to reduction in rework, which inherently uses more materials and energy than necessary. Hence, in tackling rework issues, use of materials and energy efficiency can always be included in the improvement project scope. This practice will not require more organizational resources, and furthermore, will help raise employee awareness of sustainability. Other environmental sustainability indicators, such as waste management and pollution prevention, also align well with improvement activities in these industries; however, they will require more resources than the resources improvement project needs alone. Compared to environmental indicators, mapping social sustainability indicators in these types of industries is more challenging mainly as their inclusion will enlarge the scope of the project and will require more organizational resources. More importantly though, inclusion of social sustainability indicators will require knowledge and practice that goes beyond field specific expertise.

In service industries, the situation is almost the opposite, i.e. it is less challenging to link social sustainability indicators to improvement projects than integrating environmental sustainability indicators. This is because service industries are more labor-intensive and the services provided can impact larger populations such as in healthcare, education, banking and government. Nevertheless, some goals and metrics will naturally align with the project goals and will not require additional resources, but others may not be as straightforward to link. For example, in the linen loss project, training employees in linen usage policies and procedures and increasing linen awareness were part of the improvement efforts that targeted the original project goals. Healthcare linen is a critical focus of the healthcare industry because of its impact on quality and cost. Hence, the project outcomes not only helped the hospital to address linen related issues but also allowed to impact individuals' development. On the other hand, in 
streamlining the hospital discharge process example, the social sustainability indicator and the related measures identified, which are targeting community support resources, did not directly correspond to any improvement activity or outcome that was in the original project. This scenario expands the scope of the project and requires additional work.

Studies in Table 5 show examples of embedding environmental and social sustainability indictors into LSS efforts explicitly, but do not address economic sustainability indictors. This is not because the approach fails to function in this area, but rather due to the dimension of sustainability in question. Economic sustainability refers to practices that support long-term economic growth without compromising other dimensions of sustainability. Many social and environmental sustainability efforts have economic sustainability as an outcome either directly or indirectly. Recycling, energy conservation, hiring, purchasing, community contributions such as providing job opportunities and supporting educational institutions are some examples.

Aside from linking sustainability indicators to the improvement project and its impacts on project scope and resource requirements, issues that exist in embedding sustainability into organizational culture will too have an effect on the implementation of the model. Support and commitment from top management, team building, and motivation are still important factors to consider (Bertels et.al., 2010; Kumar et.al., 2015). Furthermore, the effective implementation of this model requires LSS practitioners trained in sustainability. Including a sustainability expert from the company in the LSS project team might be an alternative approach to address this issue. Finally, the control phase activities might involve monitoring plans with longer timelines as some of the sustainability metrics might not be measured in short term.

\section{Conclusions, Limitations and Future Work}

There is general agreement that the concept of sustainability needs to be more integrated into 
the operations of businesses and institutions, either due to increasing public interest, regulatory pressures, or corporate social responsibility. However, the means in which that is to come about needs further work for it to be broadly applicable. The study presented herein is an attempt to bring a structured approach, a model framework that will facilitate integration and adoption of sustainability in that regard. This framework redefines the lean six sigma cycle (DMAIC) to include sustainability goals as part of the improvement effort at all times. Through illustrated examples from manufacturing, healthcare and constructions we show that the proposed framework is not specific to any industrial sector but rather is a generic framework applicable to all types of organizations and industries, and that tangible benefits can be achieved by embedding sustainability into LSS projects.

The main contributions of this work are the novelty of the approach presented. Existing frameworks start with a sustainability goal and utilize LSS in achieving these goals. Furthermore, their focus almost solely on environmental sustainability. The presented study aims to address the environmental, social, and economic aspects of sustainability as well as broaden its application by embedding sustainability goals in any LSS improvement project. Both academicians and professionals will benefit from the presented framework as it provides a different perspective than what is found in literature enabling broader applications, together with concrete steps and examples demonstrating its implementation, use, and potential benefits.

The major limitation of this study is that the application of the proposed framework is based on four case studies taken from the literature. Testing the framework using more case studies, and furthermore implementing in real-cases could strengthen our findings. These limitations provide the direction for our future work. 


\section{References:}

Alhaddi H., "Triple Bottom Line and Sustainability: A Literature Review", Business and Management Studies, 2015, Vol. 1., No. 2, pp. 6-10.

Allen T.T., Tsend S-H., Swanson K., McClay M.A., "Improving the Hospital Discharge Process with Six Sigma Methods", Quality Engineering, 2010, Vol. 22, pp. 13-20, 2010, doi: 10.1080/08982110903344812.

Al-Shamkhani M., and Elshennawy A.K., "Application of Six Sigma Methodology to Reduce Environmental and Economic Impacts of Discharging the Produced Water in Southern Iraqi Oil Fields", The Journal of Management and Engineering Integration, 2013, Vol. 6, No. 2, pp. $31-49$.

Anderson N.C., Kovach J.V., "Reducing Welding Defects in Turnaround Projects: A Lean Six Sigma Case Study", Quality Engineering, 2014, Vol.26, No.2, pp. 168-181,doi: 10.1080/08982112.2013.801492.

Antony J., Snee R., and Hoerl R., "Lean Six Sigma: Yesterday, Today and Tomorrow", International Journal of Quality \& Reliability Management, 2017, Vol. 34, No. 7, pp. 10731093, doi:10.1108/IJQRM-03-2016-0035.

Banawi A., and Bilec M. "A Framework to Improve Construction Processes: Integrating Lean, Green and Six Sigma", International Journal of Construction Management, 2014, Vol. 0, No. 0, pp. 1-14, doi:10.1080/15623599.2013.875266.

Bonvoisin J., Stark R., Seliger G. (2017) Field of Research in Sustainable Manufacturing. In: Stark R., Seliger G., Bonvoisin J. (eds) Sustainable Manufacturing. Sustainable Production, Life Cycle Engineering and Management. Springer, Cham

Bertels S., Papania L., and Papania D., "Embedding Sustainability in Organizational culture: A Systematic Review of the Body of Knowledge" (2010). London, Ontario, Canada: Network for Business Sustainability $74 \mathrm{pp}$. Available at https://nbs.net/p/systematic-review-organizationalculture-c19ebd3b-51ff-4c61-865d-9ec4f3154a $8 \mathrm{f}$

Bhanot N., Rao V., and Deshmukh S.G., "Enablers and Barriers of Sustainable Manufacturing: Results from a Survey of Researchers and Industry Professionals", Procedia CIRP 29, 2015 pp. 562-567, doi: 10.1016/j.procir.2015.01.036. 
Calia R.C., Guerrini F.M., Castro M., "The Impact of Six Sigma in the Performance of a Pollution Prevention Program", Journal of Cleaner Production, 2009, Vol. 17. pp. 1303-1310, doi:10.1016/j.jclepro.2009.05.001.

Cherrafi A., Elfezazi S., Govindan K., Garza-Reyes J., Behnda K., and Mokhlis A., "A Framework for the Integration of Green and Lean Six Sigma for Superior Sustainability Performance", International Journal of Production Research, 2016a, doi:10.1080/00207543.2016.1266406.

Cherrafi A., Elfezazi S., Chiarini A., Mokhlis A., and Benhida K., "The Integration of Lean Manufacturing, Six Sigma and Sustainability: A Literature Review and Future Research Directions for Developing a Specific Model”, Journal of Cleaner Production, 2016b, Vol. 139, pp. 828-846, doi:10.1016/j.jclepro.2016.08.101.

Cherrafi A., Elfezazi S., Chiarini A., Mokhlis A., and Benhida K., "Exploring Critical Success Factors for Implementing Green Lean Six Sigma", International Manufacturing Strategy in a Time of Great Flux, Brennan L. and Vecchi A., (eds) Measuring Operations Performance, 2017, doi:10.1007/978-3-319-25351-0_9.

Chugani N., Kumar V., Garza-Reyes J.A., Rocha-Kona L., and Upadhyay A., "Investigating the Green Impact of Lean, Six Sigma and Lean Six Sigma: A Systematic Literature Review", International Journal of Lean Six Sigma, 2017, Vol. 8, No. 1, pp. 7-32, doi:10.1108/IJLSS-112015-0043.

Cinelli M., Coles S.R., Kirwan K., "Analysis of the potentials of multi criteria decision analysis methods to conduct sustainability assessment", Ecologicla Indicators, 2014, Vol. 46, pp. 138148. doi:10.1016/j.ecolind.2014.06.011

Deif, A.M., “A system model for green manufacturing”, Journal of Cleaner Production, 2011, Vol. 19, pp. 1553-1559, doi:10.1016/j.jclepro.2011.05.022.

Donabedian A. "Evaluating the Quality of Medical Care", Milbank Memorial Fund Q. 1966; Vol. 44, No. 3 (suppl) pp. 166 - 206. Reprinted in Milbank Q. 2005, Vol. 83, No. 4, pp. 691 729.

Elkington, J, "Towards the Sustainable Corporation: Win-Win-Win Business Strategies for Sustainable Development”, California Management Review, 1994, Vol. 36 No. 2, pp. 90-100, doi: $10.2307 / 41165746$.

EPA, United States Environmental Protection Agency 2017. Lean @EPA. www.epa.gov/Lean 
EPA, United States Environmental Protection Agency, 2006 (revised October 2007). The Lean and Environment Toolkit. Available at https://www.epa.gov/lean/lean-environment-toolkit

EPA, United States Environmental Protection Agency, 2009. The Lean and Chemicals Toolkit. Available at https://www.epa.gov/lean/lean-chemicals-toolkit

EPA, United States Environmental Protection Agency, 2011. Lean, Energy \& Climate Toolkit. Available at https://www.epa.gov/lean/lean-energy-and-climate-toolkit

EPA, United States Environmental Protection Agency, 2011. Lean and Water Toolkit. Available at https://www.epa.gov/lean/lean-water-toolkit

EPA, United States Environmental Protection Agency, 2014. DOSII. Available at https://www.epa.gov/sites/production/files/2016-10/dosii.xlsx

European Commission. 2014. Lean Product and Process Development Report Summary. Available at http://cordis.europa.eu/project/ren/89915_en.html

Evans J.R., and Lindsay W.M., "An Introduction to Six Sigma \& Process Improvement” Second Edition, 2015, Cengage Learning, Stamford, CT.

Finkbeiner, M., Schau, E.M., Lehmann, A., and Traverso, M., "Towards Life Cycle Sustainability Assessment", Sustainability, 2010, Vol. 2, No. 10, pp. 3309-3322, doi:10.3390/su2103309.

Freitas J.G., Costa H.G., and Ferraz F.T., “ Impacts of Lean Six Sigma over Organizational Sustainability: A Survey Study”, Journal of Cleaner Production, 2017, Vol. 156, pp. 262-275, doi:10.1016/j.jclepro.2017.04.054

Furterer S.L, "Applying Lean Six Sigma to Reduce Linen Loss in an Acute Care Hospital" International Journal of Engineering, Science and Technology, Vol. 3, No. 7, pp-39-55, 2011, doi:10.4314/ijest.v3i7.4S.

Garza-Reyes J.A., Villarreal B., Kumar V., and Ruiz P.M., "Lean and Green in the Transportation and Logistics Sector - A Case Study of Simultaneous Deployment", Production Planning and Control, 2016, Vol. 27, No. 15, pp. 1221-1232, doi:10.1080/09537287.2016.1197436

Garza-Reyes J.A., "Green Lean and The Need for Six Sigma", International Journal of Lean Six Sigma, 2015, Vol. 6, No. 3, pp. 226-248, doi:10.1108/IJLSS-04-2014-0010.

Gatto M., "Sustainability: Is it a Well Defined Concept?", Ecological Applications, 1995, Vol. 5, No. 4, pp.1181-1183. 
Global Reporting Initiative (GRI), 2011 Amsterdam, Netherlands, "Sustainability Reporting Guidelines on Economic, Environmental, and Social Performance." Available at www.globalreporting.org/resourcelibrary/G3.1-Guidelines-Incl-Technical-Protocol.pdf

Gupta V., Narayanamurthy G., and Acharya P., "Can Lean Lead to Green? Assessment of Radial Tyre Manufacturing Processes Using System Dynamics Modeling", Computers and Operations Research, 2018, Vol. 89, pp. 284-306, doi:10.1016/j.cor.2017.03.015.

Hartini S., and Ciptomulyono U., "The Relationship Between Lean and Sustainable Manufacturing on Performance: Literature Review”, Procedia Manufacturing, 2015, Vol. 4, pp. 38-45, doi: 10.1016/j.promfg.2015.11.012.

Ismyrlis V. and Moschidis O., "Six Sigma's Critical Success Factors and Toolbox”, International Journal of Six Sigma, 2013, Vol. 4, No. 2, pp. 108-117, doi:10.1108/20401461311319310.

Jirasukprasert P., Garza-Reyes J.A., Kumar V., and Lim M.K., "A Six Sigma and DMAIC Application for the Reduction of Defects in a Rubber Gloves Manufacturing Process", International Journal of Lean Six Sigma, 2013, Vol. 5, No. 1, pp. 2-21, doi:10.1108/IJLSS-032013-0020.

Johnston P., Everard M., Santillo D., Robert K.-H., "Reclaiming the Definition of Sustainability", Environmental Science and Pollution Research International, 2007, Vol.14, No. 1, pp. 60-66, doi:10.1065/espr2007.01.375.

Khalili N.R., Duecker S., Ashton W., Chavez F., "From Cleaner Production to sustainable Development: The Role of Academia", Journal of Cleaner Production, 2015, Vol. 96, No. 1, pp. 30-43. doi:10.1016/j.jclepro.2014.01.099.

Kumar S., Kumar N., and Haleem A., "Conceptualization of Sustainable Green Lean Six Sigma: an Empirical Analysis", International Journal of Business Excellence, 2015, Vol. 8, No. 2, pp. 210-250.

Lee, J., Yuvamitra, K., Guiberteau, K. and Kozman, T.A., "Six-Sigma Approach to Energy Management Planning", Strategic Planning for Energy and the Environment, 2014, Vol. 33 No. 3, pp. 23-40.

Meisel, R.M., Babb, S.J., Marsh, S.F. and Schlichting, J.P. (2007), Executive Guide to Understanding and Implementing Lean Six Sigma - The Financial Impact, American Society for Quality.

Miguel P.A.C., Satolo E., Andrietta J.M., and Calarge F.A., "Benchmarking the Use of Tools 
and Techniques in the Six Sigma Programme Based On a Survey Conducted In a Developing Country", Benchmarking: An International Journal, 2012, Vol.10, No. 6, pp. 690-70, doi:10.1108/14635771211284279.

Missimer M., "Social Sustainability within the Framework for Strategic Sustainable Development", Blekinge Institute of Technology, Doctoral Thesis, 2015.

Mittal V.K., and Sangwan K.S., "Prioritizing Barriers to Green Manufacturing: Environmental, Social and Economic Perspectives", Procedia CIRP 17, 2014, pp. 559-564, doi: 10.1016/j.procir.2014.01.075.

Morelli J., "Environmental Sustainability: A Definition for Environmental Professionals", 2011, Vol. 1, No. 1, doi: 10.14448/jes.01.0002.

Pampanelli A.B., Found P., and Bernardes A.M., "A Lean \& Green Model for a Production Cell”, Journal of Cleaner Production, 2014, Vol. 85, 2014, pp. 19-30, doi:10.1016/j.jclepro.2013.06.

Resta B., Dotti S., Gaiardelli P., and Boffelli A., "Lean Manufacturing and Sustainability: An Integrated View", In: Nääs I. et al. (eds) Advances in Production Management Systems. Initiatives for a Sustainable World. APMS 2016. IFIP Advances in Information and Communication Technology, Vol. 488. Springer, Cham.

Salem A. and Deif A., "Developing a Greenometer for Green Manufacturing Assessment", Journal of Cleaner Production, 2017, Vol.154, pp. 413-423, doi:10.1016/j.jclepro.2017.03.196.

Santoyo-Castelazo E., and Azapagic A., "Sustainability Assessment of Energy Systems: Integrating Environmental, Economic and Social Aspects", Journal of Cleaner Production, 2014, Vol. 80, No. 1, pp. 119-138. doi:10.1016/j.jclepro.2014.05.061.

Sezen B, and Cankaya S.Y., "Effects of Green Manufacturing and Eco-innovation on Sustainability Performance", Procedia - Social and Behavioral Sciences, 2013, Vol. 99, pp.154-163, doi:10.1016/j.sbspro.2013.10.481.

Souza R.G., Rosenhead J., Salhofer S.P., Valle R.A.B., and Lins M.P.E., "Definition of Sustainability Impact Categories Based on Stakeholder Perspectives”, Journal of Cleaner Production, 2015, Vol. 105, pp. 41-51. doi:10.1016/j.jclepro.2014.09.051.

Sutherland J.W., Richter J.S., Hutchins M.J., Dornfeld D., Dzombak R., Mangold J., Robinson S., Hauschild M.Z., Bonou A., Schonsleben P. and Friemann F., "The Role of Manufacturing 
in Affecting the Social Dimension of Sustainability", CIRP Annals-Manufacturing Technology, 2016, Vol. 65, No.2, pp. 689-712, doi:10.1016/j.cirp.2016.05.003.

Torielli R.M., Abrahams R.A., Smillie R.W., and Voigt R.C., "Using Lean Methodologies for Economically and Environmentally Sustainable Foundries”, China Foundry, 2011, Vol. 8, No.1, pp. 74-88.

Uluskan M., "A Comprehensive Insight into the Six Sigma DMAIC Toolbox", International Journal of Lean Six Sigma, 2016, Vol.7, No. 4, pp. 406-429, doi:10.1108/IJLSS-10-20150040 .

Uluskan M., “Analysis of Lean Six Sigma Tools from a Multidimensional Perspective”, Total Quality Management \& Business Excellence, 2017, doi:10.1080/14783363.2017.1360134.

UNEP, "A Guide for the Assessment of the Costs and Benefits of Sustainability Certification", Trade, Policy, and Planning Unit of the Economy and Trade Branch. 2016. Available at http://web.unep.org/greeneconomy/resources/publication?page=1

Vais A., Miron V., Pedersem M., and Folke J., "Lean and Green at a Romanian secondary tissue paper and board mill - putting theory into practice", Resources, Conservation and Recycling, 2006, Vol. 46, pp. 44-74, doi:10.1016/j.resconrec.2005.06.005.

Verrier B., Rose B., and Caillaud E., "Lean and Green Strategy: the Lean and Green House and Maturity Deployment Model", Journal of Cleaner Production, 2016, Vol. 116, pp. 150-156, doi:10.1016/j.jclepro.2015.12.022.

Waas T., Huge J., Block T., Wright T., Benitez-Capistros F., and Verbruggen A., "Sustainability Assessment and Indicators: Tools in a Decision-Making Strategy for Sustainable Development", Sustainability, 2014, Vol. 6, No. 9, pp. 5512-5534. doi:10.3390/su6095512.

WCED, "Report of the World Commission on Environment and Development: Our Common Future", United Nations World Commission on Environment and Development, Oslo, March 1987.

Wong WP., and Wong KY., "Synergizing an Ecosphere of Lean for Sustainable Operations", Journal of Cleaner Production, 2014, Vol. 85, pp.51-66, doi:10.1016/j.jclepro.2014.05.093. 